\title{
Accumulation, assimilation and growth inhibition of copper on freshwater alga (Scenedesmus subspicatus 86.81 SAG) in the presence of EDTA and fulvic acid
}

\author{
Mei Ma ${ }^{\mathrm{a}}$, Wangzhao Zhu ${ }^{\mathrm{b}}$, Zijian Wang ${ }^{\mathrm{a}, *}$, Geert J. Witkamp ${ }^{\mathrm{b}}$ \\ ${ }^{a}$ SKLEAC, Research Center for Eco-Environmental Sciences, Chinese Academy of Science, P.O. Box 2871, Beijing 100085, People's \\ Republic of China \\ ${ }^{\mathrm{b}}$ Laboratory for Process Equipment, Delft University of Technology, Delft, The Netherlands
}

Received 1 March 2002; received in revised form 18 September 2002; accepted 19 September 2002

\begin{abstract}
Accumulation and growth inhibition of $\mathrm{Cu}$ to fresh water alga (Scenedesmus subspicatus $86.81 \mathrm{SAG}$ ) and the influences of ethylenediaminetetraacetic acid (EDTA) and fulvic acid (FA) were examined. These results demonstrated that both EDTA and FA could reduce toxicity of $\mathrm{Cu}$ to alga by the way of preventing $\mathrm{Cu}$ from being adsorbed by cell wall of alga. When dissolved $\mathrm{Cu}\left(\mathrm{Cu}_{\text {dissolved }}\right)$, extracellular $\mathrm{Cu}\left(\mathrm{Cu}_{\text {extracellular }}\right)$, and intracellular $\mathrm{Cu}\left(\mathrm{Cu}_{\text {intracellular }}\right)$ were differentiated, our results showed that the concentration level of extracellular $\mathrm{Cu}\left(\left[\mathrm{Cu}_{\text {extracellular }}\right]\right)$ was a good indicator for measuring the toxic effects of $\mathrm{Cu}$ on alga growth in complex matrix. Either in the absence or in the presence of EDTA and FA, the concentration of intracellular $\mathrm{Cu}$ increased to $0.6-1.5 \times 10^{-8} \mu \mathrm{M}$ per cell when the growth inhibition reached to about $50 \%$. We found that the acute toxicity of copper on unicellular alga could be interpreted by its accumulation at a discrete site or biotic ligand at alga cell wall and critical accumulation of $\mathrm{Cu}$ associated with $\mathrm{EC}_{50}$ was determined to be $1 \times 10^{-8} \mu \mathrm{M}$ per cell. Therefore, the Biotic Ligand Model (BML) could be extended to predict the influence of copper on growth inhibition of alga.
\end{abstract}

(C) 2002 Elsevier Science B.V. All rights reserved.

Keywords: Copper; Toxicity; Alga; FIAM; BLM

\section{Introduction}

Copper is ubiquitous in the environment. Its presence in aquatic systems arises from a variety of

\footnotetext{
* Corresponding author. Tel.: +86-10-6284-9140; fax: +8610-6292-3543

E-mail address: wangzj@mail.rcees.ac.cn (Z. Wang).
}

point and non-point source discharges, of both naturally occurring and man-made origin. Although $\mathrm{Cu}$ is an essential element, which is required for the proper sustenance of all plants and animals, including aquatic life (Lee and Allen, 1998; Landner and Lindestrom, 1999; Sigg et al., 1999), at elevated levels $\mathrm{Cu}$ becomes toxic. Therefore, $\mathrm{Cu}$ contamination has drawn great attention in the past few decades. Regulating the discharge 
of $\mathrm{Cu}$ to the environment is vitally important. To develop water quality criteria (WQC) for $\mathrm{Cu}$, it requires an understanding of how much $\mathrm{Cu}$ is discharged in the environment and how much actually causes toxic effects in the environment.

It has become apparent that the toxic effects of heavy metals towards aquatic organisms depend not only on their concentrations but also on the forms of their occurrence. Predicting metal toxicity through certain kinds of indicator is, therefore, the pursuing of researchers. In previous studies, much work indicated that the activity of free $\mathrm{Cu}$ ions in bulk aqueous phase is a good predictor for $\mathrm{Cu}$ toxicity to many biological species (Sunda and Guillard, 1976; Anderson and Morel, 1978; Brand et al., 1986; Moffett and Brand, 1996). The $\mathrm{Cu}$ uptake has, therefore, been described by the freeion-activity model (FIAM; Morel and Hering, 1993), which has been interpreted to imply that a constant degree of biological effect will occur at a constant chemical activity of the free metal ion, independent of other water quality parameter. However, the free-ion activity does not appear to be a good predictor of toxicity across some waterquality conditions (Campbell, 1995). The recent development on the prediction of $\mathrm{Cu}$ toxicity was based on the Biotic Ligand Model (BLM; International Copper Association, 2000), in which freeion activity is a necessary but not sufficient component to describe metal accumulation and toxicity. The toxicity of metals to organisms is assumed to occur as the result of free metal ion reaction with the physiologically active binding sites and the accumulation at the binding sites is controlled by the free $\mathrm{Cu}$ concentration in aqueous phase. By using the BLM, accumulation of $\mathrm{Cu}$ at the biotic ligand at a critical level can be used to predict $\mathrm{Cu}$ toxicity over a broad range of water quality conditions. BLM has been developed for fathead minnows, Daphnia pulex and Ceriodaphnia dubia, based on the assumption that acute toxicity of $\mathrm{Cu}$ should be interpreted by its accumulation at specific sites on the cell membrane (International Copper Association, Ltd., 2000). BLM has not been extended to predict the toxicity of $\mathrm{Cu}$ to unicellular alga.
An alternative in predicting toxicity of metals in complex matrix is the use of internal dose. Toxic effects are observed in aquatic organisms when the body burden of toxic metals reaches some critical level. The advantage of using internal dose is that it may avoid the interferences of matrix effects from biological accumulation. But if the chemical substance acts through a different mode of toxic action, the same level of toxicity occurs at lower internal dose exposed to biota (Jarvinen and Ankey, 1999).

In this study, unicellular freshwater alga (Scenedesmus subspicatus $86.81 \mathrm{SAG}$ ) was used to evaluate the toxicity of $\mathrm{Cu}$ in the presence of EDTA, a synthetic organic ligand and FA, a typical natural existing organic ligand. The aim of this study was to determine toxic predictor among different forms of $\mathrm{Cu}$ in aqueous phase and to differentiate whole body burden from extracellular $\mathrm{Cu}$ concentration to elucidate the mode of toxic action in freshwater alga. Through the results, both external and internal dose-effect relationship were compared.

\section{Materials and methods}

\subsection{Reagents and plasticware}

All plastic ware and glassware were soaked for at least $24 \mathrm{~h}$ in $10 \% \mathrm{HNO}_{3}$, thoroughly rinsed with ultrapure water (ELGA, UK). All the chemicals used for cultures and experiments were of analytical grade or better. The culture medium and all the other solutions were prepared with ultrapure water. Stock solution of $\mathrm{Cu}$ was prepared from analytical grade $\mathrm{CuSO}_{4} \cdot 5 \mathrm{H}_{2} \mathrm{O}$ (Backer Analyzed Reagent, J.T. Baker, The Netherlands) and diluted to test solution on the day of use from the stock. Stock solution of EDTA was prepared from its sodium salt (Fluka ACS, Germany) and diluted 100 -fold for preparation of test solution. The FA was extracted from the sediment collected from Guanting Reservoir in Beijing, China and was purified by following the method described previously (Wang, 1987). The test solution was prepared from stock solution of $\mathrm{Cu}$, stock 
solution of EDTA or FA, as well as culture medium.

\subsection{Bioassays}

The bioassays were carried out following the method of OECD-guideline 201 (OECD, 1984). Unicellular freshwater green alga was kindly provided by Netherlands Organization for Applied Scientific Research (TNO). Culture medium for alga was prepared according to OECD-guideline 201 (OECD, 1984) and $\mathrm{pH}$ was adjusted to 8.0. Alga was grown at a photon irradiance of approximately $120 \mu \mathrm{M} \mathrm{m} \mathrm{m}^{-2} \mathrm{~s}^{-1}$ (cool white fluorescent tubes) in a $12 \mathrm{~h}$ light: $12 \mathrm{~h}$ dark regime by constant shaking at $100 \mathrm{rpm}$ and temperature of $25 \pm 2{ }^{\circ} \mathrm{C}$. The bioassays were performed in 250-ml polycarbonate flasks (Erlenmeyer flasks from NALGENE ${ }^{\circledR}$ ) to minimize adsorptive losses of $\mathrm{Cu}$ to the wall of containers, and over as short as possible time period ( $72 \mathrm{~h}$ ) to minimize possible effects of algal exudates.

To prepare the test solution, 1-ml stock solution of EDTA and 1-ml stock solution of $\mathrm{Cu}$ were added to a $250-\mathrm{ml}$ polycarbonate flask and the final volume was adjusted to $100-\mathrm{ml}$ with OECDmedium. In the experiments, two different levels of EDTA (17 and $34 \mu \mathrm{M})$ and three levels of FA (1.0, 2.5 and $\left.5.0 \mathrm{mg}^{-1}\right)$ were used, respectively. Each treatment consisted of five concentration levels of $\mathrm{Cu}$ and a control. Four replicates of test solution for each concentration level of $\mathrm{Cu}$ or control were prepared. One flask in each treatment was used for the determination of the total added $\mathrm{Cu}$ concentration and the remaining three flasks were added with alga and were used for bioassay and the differentiation of $\mathrm{Cu}$. In the treatments with EDTA and the treatment with $\mathrm{Cu}$ alone, $\mathrm{Cu}$ concentrations ranged from 10 to $160 \mu \mathrm{M}$ by a 0.5 -fold dilution series. However, in the presence of FA, as precipitation occurred at high $\mathrm{Cu}$ concentration, concentrations of $\mathrm{Cu}$ were tested between the range from 2.5 to $40 \mu \mathrm{M}$ by a 0.5 -fold dilution series.

The test cultures were inoculated with exponential-phase algal cells from the stock culture. The initial cell concentration was approximately $2 \times$ $10^{4}$ cells per $\mathrm{ml}$. The absorbance of alga suspen- sion was measured at $625 \mathrm{~nm}$ on a spectrophotometer (HITACHI U-1100) at 24, 48 and $72 \mathrm{~h}$ after the start of the culture. The cell density was obtained using a calibration curve of absorbance versus cell number, which was counted by using a microscope. The $\mathrm{pH}$ of solution was checked after $72 \mathrm{~h}$ to ensure that it did not vary by more than 1.0 $\mathrm{U}$.

The percentage of growth inhibition in relation to the control was calculated from the total amount of $\mathrm{Cu}$ in the culture. The concentration that leads to $50 \%$ growth reduction was calculated according to OECD-guideline 201 (OECD, 1984) and was recorded as $\mathrm{EC}_{50}$.

\subsection{Chemical measurements and differentiating forms of $\mathrm{Cu}$}

The method we used to distinguish the extracellular $\mathrm{Cu}$ and intracellular $\mathrm{Cu}$ was followed the procedure described by Franklin et al. (2000). They used $0.02 \mathrm{M}$ EDTA to remove the $\mathrm{Cu}$ bound to Chlorella sp. and found EDTA treatment did not cause cell lysis. Shortly, at the end of the bioassay, $40.0 \pm 0.1 \mathrm{~g}$ of suspension from each flask was centrifuged for $20 \mathrm{~min}$ at $3500 \mathrm{rpm}$ and $10-\mathrm{ml}$ of supernatant was transferred into a polycarbonate tube. Concentrated $\mathrm{HNO}_{3}$ was added to the solution to a final concentration of $3 \%$, followed by $\mathrm{HR}-\mathrm{ICP}-\mathrm{MS}$ (Finnigan MAT Element, Germany) measurement to measure the dissolved $\mathrm{Cu}$ concentration. The suspension from each flask was centrifuged for $5 \mathrm{~min}$ at $3500 \mathrm{rpm}$ in order to obtain a distinct algal pellet. The supernatant was discarded and the algal pellet was resuspended in $15-\mathrm{ml}$ of $0.02 \mathrm{M}$ EDTA. The suspension was shaken for approximately $30 \mathrm{~s}$ to remove $\mathrm{Cu}$ adsorbed on the cell walls then centrifuged for another $20 \mathrm{~min}$ at $4000 \mathrm{rpm}$. The supernatant was used to measure the extracellular $\mathrm{Cu}$ concentration by $\mathrm{HR}-\mathrm{ICP}-\mathrm{MS}$. The algal pellets were left to dry and then acid-digested with 2-ml of concentrated $\mathrm{HNO}_{3}$ at $90{ }^{\circ} \mathrm{C}$ over night. The samples were diluted by ultrapure water until the $\mathrm{HNO}_{3}$ is approximately $3 \%$ and then analyzed for intracellular $\mathrm{Cu}$ concentration by HR-ICP-MS. 


\subsection{Quality control}

In the HR-ICP-MS measurement, calibration was made from standard solution containing 1000 $\mathrm{mg} 1^{-1}$ of $\mathrm{Cu}$ stock solution (Perkin-Elmer Co., the Netherlands). ${ }^{115}$ In was used as an internal standard which was for optimizing the operating parameters and ion lens voltages. Ultrahigh sensitivity element $\mathrm{CD}$ was used to achieve the highest sensitivity for the determinations at $\mathrm{ng}^{-1}$ range in complicated sample matrices. In order to reduce the risk of contamination, sample manipulation was carried out in a clean bench. Before each measurement, all container and chemical were checked for background contamination. Nebulizer, spray chamber, torch, Teflon tubes etc. were cleaned with $\mathrm{HNO}_{3}(7 \mathrm{M}, 24 \mathrm{~h})$ and rinsed with ultrapure water $\left(18.2 \mathrm{M} \Omega \mathrm{cm}^{-1}\right)$. Recoveries were checked with standard addition of $\mathrm{Cu}$. A 3\% v/v $\mathrm{HNO}_{3}$ (65\% Merck, suprapur) solution was used for washing the tubes in order to remove any contamination and 'memory effect' prior to sample and standard introduction to the HR-ICPMS. Typical instrument conditions for the HRICP-MS and sample introduction system were listed in Table 1.

\section{Results and discussion}

Percentages of growth inhibition and concentrations of different forms of $\mathrm{Cu}$ with and without EDTA were shown in Table 2. From the results,

Table 1

Instrument condition for the $\mathrm{HR}-\mathrm{ICP}-\mathrm{MS}$ and sample introduction system

\begin{tabular}{ll}
\hline Sample (Nebuilizer) gas flow rate & $1.051 \mathrm{~min}^{-1}$ \\
Auxiliary gas flow rate & $11 \mathrm{~min}^{-1}$ \\
Plasma gas flow rate & $16.91 \mathrm{~min}^{-1}$ \\
RF power & 1240 \\
Sample liquid flow rate & $50 \mu 1 \mathrm{~min}^{-1}$ \\
Resolution mode & Low and middle \\
Resolution & 300 and 3000 \\
Scanning mode & E-scan \\
Measurement time & 0.10 \\
Measurements per peak & 20 \\
Numbers of scans $\times$ passes & $5 \times 5$ \\
\hline
\end{tabular}

algal growth was significantly inhibited when total concentration of $\mathrm{Cu}$ in the culture was increased. The correlation coefficients between the percentage of inhibition and total $\mathrm{Cu}$ concentrations were $0.937,0.865$ and 0.960 corresponding to EDTA levels of 0,17 and $34-\mu \mathrm{M}$. Significant correlations could also be found between the percentage of inhibition and dissolved $\mathrm{Cu}$ concentration or extracellular $\mathrm{Cu}$ concentration. In fact, both dissolved and extracellular $\mathrm{Cu}$ concentrations increased significantly with the increase of total $\mathrm{Cu}$ concentration at different concentration levels of EDTA $(r>0.97)$. In the treatments containing 17 and $34 \mu \mathrm{M}$ of EDTA, more $\mathrm{Cu}$ remained in aqueous phase and the concentration of extracellular $\mathrm{Cu}$ was significantly reduced. As EDTA and divalent metal forms 1:1 complex in aqueous phase and the complex is non-bioavailable for alga adsorption or absorption (Allison and Brown, 1991) it was reasonable that the increase of extracellular $\mathrm{Cu}$ occurred at higher total $\mathrm{Cu}$ concentration when concentration of EDTA was higher.

In Table 2, total $\mathrm{Cu}$ concentrations increased from about $10-160 \mu \mathrm{M}$ and a gradual increase in algal growth inhibition was observed. The calculated 72-h $\mathrm{EC}_{50}$ in the absence of EDTA was 5.4 $\mu \mathrm{M}$. The inhibition effect was less pronounced in the presence of EDTA. Increasing EDTA concentration from 17 to $34 \mu \mathrm{M}$ resulted in a substantial increase in the $72-\mathrm{h} \mathrm{EC}_{50}$ from 31 to $60 \mu \mathrm{M}$. Our results jointed the vast evidences that the presence of EDTA reduced the toxicity of $\mathrm{Cu}$ (Wong et al., 1995; Hansten et al., 1996; Campbell et al. 2000).

It could be quite interesting to see from Table 2 that the concentration of intracellular $\mathrm{Cu}$ increased from about $1.0-1.8 \times 10^{-8} \mu \mathrm{M}$ per cell when the inhibition reached to about $50 \%$ either in the absence or in the presence of different concentrations of EDTA. The result clearly indicated that the growth inhibition of alga was closely related to the binding of $\mathrm{Cu}$ on alga cell wall and the translocation of $\mathrm{Cu}$ crossing cell membrane was retarded when concentrations of intracellular $\mathrm{Cu}$ reached about $1.0 \times 10^{-8} \mu \mathrm{M}$ per cell.

Growth inhibition and concentrations of different forms of $\mathrm{Cu}$ in the presence of FA were shown in Table 3. The natural derived FA had similar 
Table 2

Concentrations of different $\mathrm{Cu}$ forms and growth inhibition in the presence of EDTA

\begin{tabular}{|c|c|c|c|c|c|c|}
\hline$[\mathrm{EDTA}](\mu \mathrm{M})$ & {$[\mathrm{Cu}]_{\text {total }}(\mu \mathrm{M})$} & {$[\mathrm{Cu}]_{\text {dissolved }}(\mu \mathrm{M})$} & $\begin{array}{l}{[\mathrm{Cu}]_{\text {extracellular }}} \\
\left(\times 10^{-8} \mu \mathrm{M} \text { per cell }\right)\end{array}$ & $\begin{array}{l}{[\mathrm{Cu}]_{\text {intracellular }}} \\
\left(\times 10^{-8} \mu \mathrm{M} \text { per cell }\right)\end{array}$ & Growth inhibition $(\%)$ & $\Delta \mathrm{pH}$ \\
\hline \multirow[t]{5}{*}{0} & 10.5 & $4.0 \pm 0.5$ & $1.6 \pm 0.1$ & $1.4 \pm 0.1$ & 57 & 0.57 \\
\hline & 20.8 & $7.4 \pm 0.6$ & $5.1 \pm 2.9$ & $1.8 \pm 0.1$ & 63 & 0.61 \\
\hline & 40.6 & $8.6 \pm 0.9$ & $17.3 \pm 0.6$ & $1.6 \pm 0.2$ & 72 & 0.58 \\
\hline & 80.7 & $11.3 \pm 0.5$ & $62.2 \pm 4.4$ & $1.0 \pm 0.3$ & 92 & 0.63 \\
\hline & 156.1 & $17.8 \pm 0.1$ & $148.1 \pm 9.7$ & $1.5 \pm 0.5$ & 99 & 0.73 \\
\hline \multirow[t]{5}{*}{17} & 11.5 & $9.7 \pm 0.1$ & $0.3 \pm 0.0$ & $0.1 \pm 0.1$ & 1 & 0.09 \\
\hline & 24.6 & $18.0 \pm 0.9$ & $0.8 \pm 2.9$ & $0.7 \pm 0.1$ & 34 & 0.14 \\
\hline & 46.0 & $26.3 \pm 1.5$ & $4.2 \pm 0.1$ & $2.0 \pm 0.2$ & 60 & 0.20 \\
\hline & 90.2 & $26.3 \pm 0.2$ & $33.3 \pm 3.2$ & $0.7 \pm 0.2$ & 85 & 0.20 \\
\hline & 176.3 & $37.4 \pm 1.5$ & $94.4 \pm 4.0$ & $1.1 \pm 0.4$ & 95 & 0.35 \\
\hline \multirow[t]{5}{*}{34} & 9.0 & $9.3 \pm 0.0$ & $0.2 \pm 0.0$ & $0.1 \pm 0.0$ & -1 & 0.20 \\
\hline & 18.8 & $19.7 \pm 0.3$ & $0.4 \pm 0.0$ & $0.1 \pm 0.0$ & -5 & -0.30 \\
\hline & 36.9 & $36.8 \pm 0.9$ & $1.2 \pm 0.0$ & $0.8 \pm 0.0$ & 33 & 0.94 \\
\hline & 73.2 & $44.5 \pm 1.5$ & $17.6 \pm 1.0$ & $1.5 \pm 0.4$ & 57 & 0.56 \\
\hline & 146.9 & $53.0 \pm 3.0$ & $65.0 \pm 12.3$ & $1.6 \pm 0.6$ & 91 & 0.86 \\
\hline
\end{tabular}

effects of $\mathrm{Cu}$ adsorption and growth inhibition on alga as those of EDTA. When FA concentration increased, the growth inhibition and extracellular $\mathrm{Cu}$ concentration were reduced, whereas the dissolved $\mathrm{Cu}$ concentration increased. For example, at about $20 \mu \mathrm{M}$ of total $\mathrm{Cu}$, the percentage of inhibitions were 67,53 and $48 \%$ in the treatments containing $1,2.5$ and $5 \mathrm{mg}^{-1}$ of FA, respectively. At the same time, concentrations of dissolved $\mathrm{Cu}$ were 9.6, 15.0 and $15.2 \mu \mathrm{M}$, respectively, in the treatments containing $1,2.5$ and $5 \mathrm{mg}^{-1}$ of FA. The result supports the finding that the toxicity of $\mathrm{Cu}$, when regarding to its total concentration, was conditional and varied with concentration of dissolved organic matter in aquatic environment (Allen and Hansen, 1996). From Table 3, one can also noted that intracellular $\mathrm{Cu}$ concentration increased when concentration of FA increased

Table 3

Concentrations of different $\mathrm{Cu}$ forms and growth inhibition in the presence of FA

\begin{tabular}{|c|c|c|c|c|c|c|}
\hline$[\mathrm{FA}] \mathrm{mg} \mathrm{1}^{-1}$ & {$[\mathrm{Cu}]_{\text {total }}(\mu \mathrm{M})$} & {$[\mathrm{Cu}]_{\text {dissolved }}(\mu \mathrm{M})$} & $\begin{array}{l}{[\mathrm{Cu}]_{\text {extracellular }}} \\
\left(\times 10^{-8} \mu \mathrm{M} \text { per cell }\right)\end{array}$ & $\begin{array}{l}{[\mathrm{Cu}]_{\text {intracellular }}} \\
\left(\times 10^{-8} \mu \mathrm{M} \text { per cell }\right)\end{array}$ & Growth inhibition (\%) & $\Delta \mathrm{pH}$ \\
\hline \multirow[t]{5}{*}{1} & 2.5 & $0.7 \pm 0.1$ & $0.5 \pm 0.1$ & $0.2 \pm 0.1$ & 30 & -0.07 \\
\hline & 4.8 & $1.72 \pm 0.34$ & $1.1 \pm 0.1$ & $0.4 \pm 0.1$ & 37 & 0.23 \\
\hline & 8.8 & $4.45 \pm 0.1$ & $2.4 \pm 0.1$ & $0.6 \pm 0.1$ & 56 & 0.37 \\
\hline & 19.0 & $9.58 \pm 0.9$ & $5.8 \pm 0.9$ & $0.7 \pm 0.0$ & 67 & 0.25 \\
\hline & 37.0 & $12.37 \pm 1.9$ & $26.4 \pm 1.8$ & $0.9 \pm 0.1$ & 82 & 0.47 \\
\hline \multirow[t]{5}{*}{2.5} & 2.4 & $1.02 \pm 0.0$ & $0.4 \pm 0.0$ & $0.3 \pm 0.1$ & 8 & 0.22 \\
\hline & 4.9 & $1.73 \pm 0.1$ & $0.9 \pm 0.1$ & $0.6 \pm 0.2$ & 28 & 0.41 \\
\hline & 10.5 & $5.39 \pm 0.2$ & $1.6 \pm 0.1$ & $1.1 \pm 0.0$ & 40 & 0.46 \\
\hline & 21.1 & $15.04 \pm 0.9$ & $2.8 \pm 0.3$ & $1.2 \pm 0.2$ & 53 & 0.58 \\
\hline & 41.7 & $20.36 \pm 0.9$ & $12.3 \pm 1.6$ & $1.1 \pm 0.2$ & 63 & 0.85 \\
\hline \multirow[t]{5}{*}{5.0} & 2.3 & $1.4 \pm 0.7$ & $0.35 \pm 0.3$ & $0.11 \pm 0.1$ & -2 & -0.14 \\
\hline & 4.8 & $4.3 \pm 0.1$ & $0.67 \pm 0.4$ & $0.32 \pm 0.1$ & 0 & 0.29 \\
\hline & 9.6 & $6.2 \pm 1.9$ & $1.46 \pm 0.7$ & $0.70 \pm 0.1$ & 30 & -0.23 \\
\hline & 20.0 & $15.2 \pm 2.2$ & $3.77 \pm 1.5$ & $1.24 \pm 0.2$ & 48 & -0.05 \\
\hline & 38.5 & $17.6 \pm 0.3$ & $17.51 \pm 1.8$ & $1.88 \pm 0.4$ & 60 & 0.07 \\
\hline
\end{tabular}


and it increased to about $0.6-1.2 \times 10^{-8} \mu \mathrm{mol}$ per cell with a mean value of $0.9 \times 10^{-8} \mu \mathrm{mol}$ per cell when the inhibition reached to about $50 \%$ in the presence of different levels of FA. This value is quite close to that in EDTA treatments, where the increase of intracellular $\mathrm{Cu}$ was retarded at $1.0 \times$ $10^{-8} \mu \mathrm{M}$ per cell.

In our experiments, both intracellular and extracellular $\mathrm{Cu}$ concentrations increased obviously with increase of added $\mathrm{Cu}$ before intracellular $\mathrm{Cu}$ reached $1 \times 10^{-8} \mu \mathrm{M}$ per cell and $\mathrm{Cu}$ concentration reached $\mathrm{EC}_{50}$. However, intracellular $\mathrm{Cu}$ no longer increased when extracellular $\mathrm{Cu}$ increased very rapidly at $\mathrm{EC}_{50}$. Therefore, the inhibition of algal growth or acute toxicity was rather caused by binding of $\mathrm{Cu}$ on algal cell wall than by binding at intracellular active sites. This phenomenon was quite similar to that observed for fish, where the site of action of acute toxicity of $\mathrm{Cu}$ is the gill cell (Mcdonald et al., 1989).

It is well known that $\mathrm{Cu}$ toxicity to freshwater biota is markedly affected by water quality variables, such as $\mathrm{pH}$, water hardness and dissolved organic carbon concentration including biologically produced organic ligands (Xue et al., 1996). These factors modify toxicity by either increasing or decreasing the bioavailable concentration required to produce a particular biological response (Chapman, 1995). Factors other than those in aquatic environment may also affect the acute toxicity. For example, $\mathrm{Cu}$ toxicity may also be reduced due to detoxification pathway of $\mathrm{Cu}$ by the algal cell. Certain algal species, including Scenedesmus acutiformis, Chlorella fusca and Fucus vesiculosis, have been shown to release strong ligands that reduce the bioavailability of $\mathrm{Cu}$ in aqueous phase if they are released in sufficient amounts (Robinson, 1989; Gledhill et al., 1999; Rijstenbil and Gerringa, 2002). Cell wall exclusion of $\mathrm{Cu}$ and intracellular detoxification by binding to phytochelatins or polyphosphate have also been demonstrated in a variety of freshwater algal species in response to elevated $\mathrm{Cu}$ concentrations (Twiss et al., 1993; Knauer et al., 1997). However, exudation and detoxification effects were not considered in our experiment.

It was shown in Fig. 1a that when the growth inhibition was plotted versus the $\left[\mathrm{Cu}_{\text {dissolved }}\right]$, the

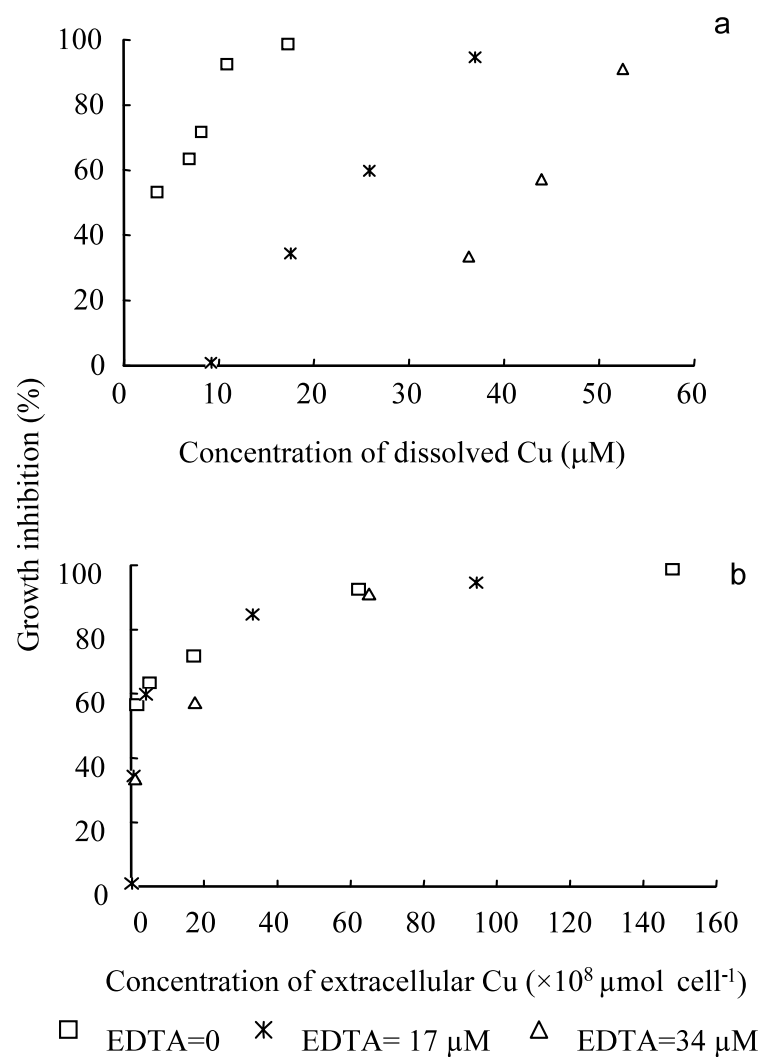

Fig. 1. (a) Influence of EDTA on the growth inhibition of $S$. Subspicatus with the increasing of dissolved $\mathrm{Cu}$ concentration (b) Influence of EDTA on the growth inhibition of $S$. Subspicatus with the increasing of extracellular $\mathrm{Cu}$ concentration.

dose-effect relationships representing three concentration levels of EDTA shifted right-ward with the increase of EDTA concentration. However, in Fig. $1 \mathrm{~b}$ when the curves were plotted as a function of $\left[\mathrm{Cu}_{\text {extracellular }}\right]$, these three curves gave almost constant prediction of toxicity. A similar observation was found in the case of FA (Fig. 2a, b), which the dose-effect relationships representing four levels of FA could be constant when plotted as a function of $\left[\mathrm{Cu}_{\text {extracellular }}\right]$.

$\mathrm{EC}_{50} \mathrm{~s}$ calculated by extracellular $\mathrm{Cu}$ concentrations were within the range of $1.2-5.410^{-8} \mu \mathrm{M}$ per cell no matter what the EDTA and FA concentrations were. However, at the three different EDTA levels tested, when $\mathrm{EC}_{50}$ s were calculated by total added $\mathrm{Cu}$ concentrations, they were 


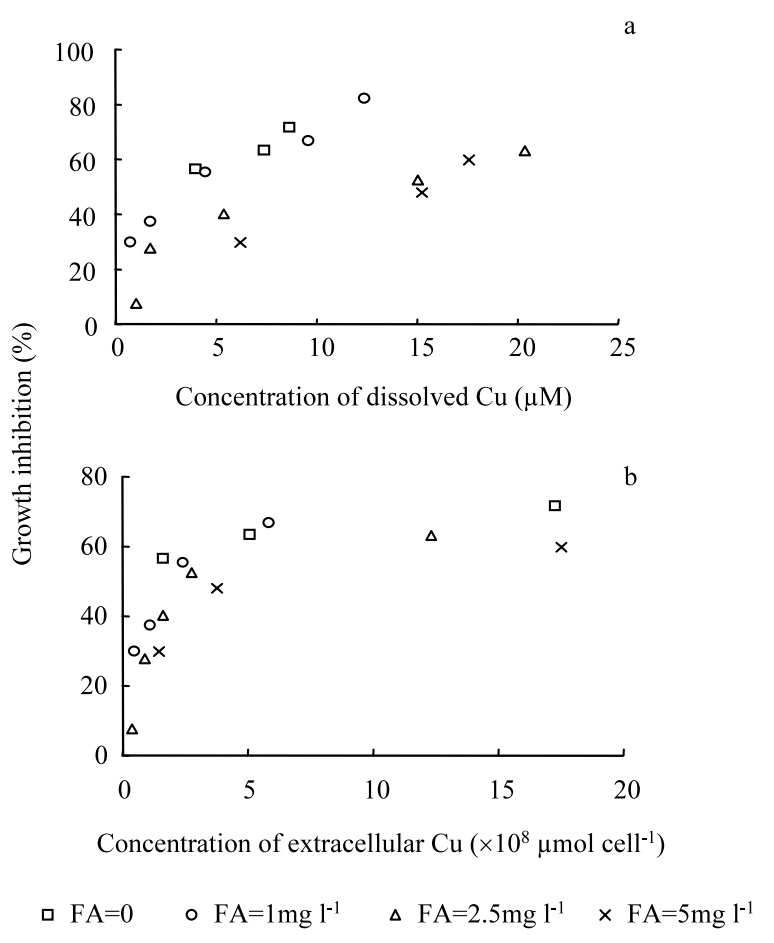

Fig. 2. (a) Influence of FA on the growth inhibition of $S$. Subspicatus with the increasing of dissolved $\mathrm{Cu}$ concentration (b) Influence of FA on the growth inhibition of S. Subspicatus with the increasing of extracellular $\mathrm{Cu}$ concentration.

5.4, 31 and $60 \mu \mathrm{M}$, respectively, while, when $\mathrm{EC}_{50} \mathrm{~s}$ were calculated by the dissolved $\mathrm{Cu}$ concentrations, they were $4.1,23$ and $42 \mu \mathrm{M}$, respectively. Large variations in $\mathrm{EC}_{50} \mathrm{~s}$ based on total $\mathrm{Cu}$ concentrations and dissolved $\mathrm{Cu}$ concentrations were obtained from the tests with addition of FA as well. Therefore, it can be concluded that $\mathrm{EC}_{50} \mathrm{~S}$ calculated by extracellular $\mathrm{Cu}$ concentrations were approximately constant in comparing with the $\mathrm{EC}_{50} \mathrm{~S}$ calculated by total added $\mathrm{Cu}$ concentrations and $\mathrm{EC}_{50} \mathrm{~s}$ calculated by dissolved $\mathrm{Cu}$ concentrations. Thus, $\left[\mathrm{Cu}_{\text {extracellular }}\right]$ is probably a good toxicity predictor in varies concentrations of organic ligands.

All the results of this study demonstrated that both EDTA and FA could reduce toxicity of $\mathrm{Cu}$ to freshwater alga $S$. subspicatus $86.81 \mathrm{SAG}$ by the way of preventing $\mathrm{Cu}$ from being adsorbed by algal cell. The results also support the applicability of BLM in predicting $\mathrm{Cu}$ toxicity because the binding sites on the algal cell (walls and/or membranes) are most likely similar to those on fish gill (Pagenkopf, 1983). According to the BLM, acute toxicity of $\mathrm{Cu}$ on alga can be described as $\mathrm{Cu}$ accumulation at a discrete site of alga cell wall or biotic ligand. Concentration of extracellular $\mathrm{Cu}$ is probably a better indicator because it does not need to consider the matrix effects in aqueous phase. Meyer et al. (1999) used fathead minnows (Pimephales promelas) to evaluate $\mathrm{Cu}$ toxicity and found that concentration of $\mathrm{Cu}$ bounded on fish gill $\left(\left[\mathrm{Cu}_{\text {gill }}\right]\right)$ was constant predictors of toxicity when the Ca concentration increases, whereas the free-ion activities of $\mathrm{Cu}$ are not constant predictors of toxicity. Di Toro (2001) used larval fathead minnow to observe the effect of variations in DOC concentration on $\mathrm{LC}_{50}$ of $\mathrm{Cu}$ and found that the gill $\mathrm{Cu}$ concentration can be used to predict acute mortality. In our study, it was found that extracellular $\mathrm{Cu}$, other than total $\mathrm{Cu}$ concentration and dissolved $\mathrm{Cu}$ concentration is of close relationship with $\mathrm{Cu}$ toxicity to alga and is approximately a good predictor of $\mathrm{Cu}$ toxicity to freshwater alga in the presence of organic ligand. The critical accumulation of $\mathrm{Cu}$ associated with $\mathrm{EC}_{50}$ was determined to be $1 \times 10^{-8} \mu \mathrm{M}$ per cell.

\section{Acknowledgements}

This study was supported by International Copper Association (ICA-TP0602) and partially supported by Chinese Academy of Sciences (KZCX2-410). The authors gratefully acknowledge Michel Van der Brink for help with HRICP-MS analysis. We would like to thank Philipp Mayer and Harry Oldersma from TNO, the Netherlands, for providing S. subspicatus 86.81 SAG and for their valuable suggestions on bioassay.

\section{References}

Allen, H.E., Hansen, D.J., 1996. The importance of trace metal speciation to water quality criteria. Water Environ. Res. 68, $283-295$.

Allison, J.D., Brown, D.S., 1991. MINTEQA2/PRODEFA2, A Geochemical Assessment Model for Environmental System: 
Version 3.0, User Manual. USEPA ERL ORD, Athens, GA57-75.

Anderson, D.M., Morel, F.M.M., 1978. Copper sensitivity of Gonyaulax tamarensis. Limnol. Oceanogr. 23, 283-295.

Brand, L.E., Sunda, W.G., Guillard, R.R.L., 1986. Reduction of marine phytoplankton reproduction rates by copper and cadmium. J. Exp. Mar. Biol. Ecol. 96, 225-250.

Campbell, P.G.C., 1995. Interactions between trace metals and aquatic organisms: a critiques of the free-ion activity model. In: tessier, A., Turner, D.R. (Eds.), Metal Speciation and Bioavailability in Aquatic System. Wiley, New York, pp. 45-102.

Campbell, C.D., Hird, M., Lumsdon, D.G., Meeussen, J.C.L., 2000. The effect of EDTA and fulvic acid on $\mathrm{Cd}, \mathrm{Zn}$, and $\mathrm{Cu}$ toxicity to a bioluminescent construct (pUCD607) of Escherichia coli. Chemosphere 40 (3), 319-325.

Chapman, J.C., 1995. The role of ecotoxicity testing in assessing water quality. Aust. J. Ecol. 20, 20-27.

Di Toro, D.M., 2001. Biotic ligand model of the acute toxicity of metals. 1. Technical basis. Envrion. Toxicol. Chem. 20 (10), 2383-2396.

Franklin, N.M., Stauber, J.L., Markich, S.J., Lim, R.P., 2000. $\mathrm{pH}$ dependent toxicity of copper and uranium to a tropical freshwater alga (Chlorella sp.). Aquatic Toxicol. 48, 275289.

Gledhill, M., Nimmo, M., Hill, S.J., 1999. The release of copper-complexing ligands by the brown alga fucus vesiculosus (phaeophyceae) in response to increasing total copper levels. J. Phycol. 35, 501-509.

Hansten, C., Heino, M., Pynnonen, K., 1996. Viability of glochidia of Anodonta anatina (Unionidae) exposed to selected metals and chelating agents. Aquatic Toxicol. 34 (1), $1-12$.

International Copper Association, 2000. The biotic Ligand Model, A Computational Approach for Assessing the Ecological Effect of Metals in Aquatic Systems. Internationl Copper Association.

Jarvinen, A.W., Ankey, G.T., 1999. Linkage of Effects to Tissue Residues: Development of a Comprehensive Database For Aquatic Organisms Exposed to Inorganic and Organic Chemicals. SETAC Press, Pensacola, FL, USA.

Knauer, K., Behra, R., Sigg, L., 1997. Effects of free $\mathrm{Cu}^{2+}$ and $\mathrm{Zn}^{2+}$ ions on growth and metal accumulation in freshwater alga. Environ. Toxicol. Chem. 16, 220-229.

Landner, L., Lindestrom, L., 1999. Copper in Society and the Environment: An Account of the Facts on Fluxes, Amounts and Effects of Copper in Sweden. Swedish Environmental Research Group (MFG), Stockholm, Sweden.
Lee, C.M., Allen, H.E., 1998. The ecological risk assessment of copper differs from that of hydrophobic organic chemicals. Hum. Ecol. Risk Assess. 4, 605-617.

Mcdonald, D.G., Reader, J.P., Dalziel, T.R.K., 1989. The combined effects of $\mathrm{pH}$ and trace metals on fish ionoregulation. In: Morris, R., Taylor, E.W., Brown, D.J.A., brown, J.A. (Eds.), Acid Toxicity and Aquatic Animals. Society of Experimental Biology Seminar Series, vol. 34. Cambridge University Press, Cambridge, pp. 221-242.

Meyer, J.S., Santore, R.C., Bobbitt, J.P., Debrey, L.D., Boese, C.J., Paquin, P.R., Allen, H.E., Bergman, H.L., Ditoro, D.M., 1999. Binding of nickel and copper to fish gills predicts toxicity when water hardness varies, but free-ion activity does not. Environ. Sci. Technol. 33, 913-916.

Moffett, J.W., Brand, L.E., 1996. Production of strong extracellular $\mathrm{Cu}$ chelators by marine cyanobacteria in response to $\mathrm{Cu}$ stress. Limnol. Oceanogr. 41, 388-395.

Morel, F.M.M., Hering, J., 1993. Principles and Applications of Aquatic Chemistry. Wiley, New York, NY, USA.

OECD, 1984. Guideline for testing of chemicals 'Alga and Growth Inhibition Test'.

Pagenkopf, G.K., 1983. Gill surface interaction model for trace-metal toxicity to fishes: role of complexation, $\mathrm{pH}$, and water hardness. Environ. Sci. Technol. 17, 342-347.

Rijstenbil, J.W., Gerringa, L.J.A., 2002. Interactions of algal ligands, metal complexation and availability, and cell responses of the diatom Ditylum brightwellii with a gradual increase in copper. Aquatic Toxicol. 56, 115-131.

Robinson, N.J., 1989. Algal metallothioneins: secondary metalbolites and proteins. J. Appl. Phycol. 1, 5-18.

Sigg, L., Behra, R., Boiler, M., Eggen, R., Meier, W., Sulzberger, B., Xue, H., 1999. Relevance of copper inputs to natural waters. EAWAG News 46, 9-11.

Sunda, W.G., Guillard, R.R.L., 1976. The relationship between cupric ion activity and toxicity of copper to phytoplankton. J. Mar. Res. 34, 511-529.

Twiss, M.R., Welbourn, P.M., Schwartzel, P., 1993. Laboratory selection for copper tolerance in Scenedesmus acutus. Can. J. Bot. 71, 333-338.

Wang, Z.J., 1987. Interaction between heavy metals and humic acid-quarsi-particle surface complexation model. Acta Sci. Circumstantiae (China) 7 (3), 313-318.

Wong, S.L., Wainwright, J.F., Pimenta, J., 1995. Quantification of total and metal toxicity in waste-water using algal bioassays. Aquatic Toxicol. 31 (1), 57-75.

Xue, H.B., Oestreich, A., Kistler, D., Sigg, L., 1996. Free cupric ion concentrations and $\mathrm{Cu}$ complexation in selected Swiss lakes and rivers. Aquatic Sci. 58 (1), 69-87. 